\title{
Using ForeStereo and LIDAR data to assess fire and canopy structure-related risks in relict Abies pinsapo Boiss forests
}

\author{
Álvaro Cortés-Molino ${ }^{\text {Corresp., } 1}$, Isabel Aulló-Maestro ${ }^{2,3}$, Ismael Fernandez-Luque ${ }^{1}$, Antonio Flores-Moya ${ }^{1}$, José A \\ Carreira $^{4}$, A Enrique Salvo ${ }^{1}$ \\ 1 Departamento de Botánica y Fisiología Vegetal, Universidad de Málaga, Málaga, Spain \\ 2 Escuela Técnica Superior de Ingeniería de Montes, Forestal y del Medio Natural, Universidad Politécnica de Madrid, Madrid, Spain \\ 3 Departamento de Silvicultura y Gestión Forestal, Instituto Nacional de Investigación y Tecnología Agraria y Alimentaria, Centro de Investigación Forestal \\ (INIA-CIFOR), Madrid, Spain \\ 4 Departamento de Biología Animal, Biología Vegetal y Ecología, Universidad de Jaén, Jaén, Spain \\ Corresponding Author: Álvaro Cortés-Molino \\ Email address: alvarocm@uma.es
}

In this study we combine information from aerial LIDAR and hemispherical images taken in the field with ForeStereo -a forest inventory device- to assess the vulnerability and to design conservation strategies for endangered Mediterranean fir forests based on the mapping of fire risk and canopy structure spatial variability. We focused on the largest continuous remnant population of the endangered tree species Abies pinsapo Boiss, spanning 252 ha in Sierra de las Nieves National Park (South Andalusia, Spain). We established 49 sampling plots over the study area. Stand structure variables were derived from ForeStereo device, an approximal sensing technology for tree diameter, height and crown dimensions and stand crown cover and basal area retrieval from stereoscopic hemispherical images photogrammetry. With this information, we developed regression models with airborne LIDAR data (spatial resolution of 0.5 points $\bullet \mathrm{m}^{-2}$ ). Thereafter, six fuel models were fitted to the plots according to the UCO40 classification criteria, and then the entire area was classified using the Nearest Neighbor algorithm on Sentinel imagery (overall accuracy of 0.56 and a KIA-Kappa Coefficient of 0.46 ). FlamMap software was used for fire simulation scenarios based on fuel models, stand structure, and terrain data. Besides the fire simulation, we analyzed canopy structure to assess the status and vulnerability of this fir population. The assessment shows a secondary growth forest that has an increasing presence of fuel models with the potential for high fire spread rate fire and burn probability. Our methodological approach has the potential to be integrated as a support tool for the adaptive management and conservation of $A$. pinsapo across its whole distribution area (< than 4000 ha), as well as for other endangered circum-Mediterranean fir forests, as. A. numidica de Lannoy and A. pinsapo marocana Trab. in North Africa 


\section{Using ForeStereo and LIDAR data to assess fire and canopy structure-related}

2 risks in relict Abies pinsapo Boiss forests

3 Álvaro Cortés-Molino ${ }^{(1)}$, Isabel Aulló-Maestro ${ }^{(2)}$, Ismael Fernández-Luque ${ }^{(3)}$, Antonio

4 Flores-Moya $^{(4)}$, José A. Carreira ${ }^{(5)}$ A. Enrique Salvo Tierra ${ }^{(6)}$

5

6

(1) alvarocm@uma.es https://orcid.org/0000-0001-5350-9028

Corresponding author. Departamento de Botánica y Fisiología Vegetal, Universidad de Málaga. Málaga, Spain.

Contributions: Conceptualization, Methodology, Formal analysis, Investigation, Writing - Original Draft.

(2) isabel.aullo@inia.es

Escuela Técnica Superior de Ingeniería de Montes, Forestal y del Medio Natural, Universidad Politécnica de Madrid. Madrid, Spain.

Departamento de Silvicultura y Gestión Forestal, Instituto Nacional de Investigación y Tecnología Agraria y Alimentaria, Centro de Investigación Forestal (INIA-CIFOR), Madrid, Spain Contributions: Methodology, Formal analysis, Resources, Writing - Review \& Editing. (3) ismaeltopografo@gmail.com

Departamento de Botánica y Fisiología Vegetal, Universidad de Málaga. Málaga, Spain.

Contributions: Methodology, Writing - Review \& Editing

(4) floresa@uma.es https://orcid.org/0000-0002-0940-4541 
Departamento de Botánica y Fisiología Vegetal, Universidad de Málaga. Málaga, Spain.

Contributions: Supervision, Validation, Writing - Review \& Editing,

(5) jafuente@uja.es https://orcid.org/0000-0002-5995-076X 
46 and then the entire area was classified using the Nearest Neighbor algorithm on Sentinel imagery

47 (overall accuracy of 0.56 and a KIA-Kappa Coefficient of 0.46). FlamMap software was used for

48 fire simulation scenarios based on fuel models, stand structure, and terrain data. Besides the fire

49 simulation, we analyzed canopy structure to assess the status and vulnerability of this fir

50 population. The assessment shows a secondary growth forest that has an increasing presence of

51 fuel models with the potential for high fire spread rate fire and burn probability. Our

52 methodological approach has the potential to be integrated as a support tool for the adaptive

53 management and conservation of $A$. pinsapo across its entire distribution area ( $<4000 \mathrm{ha})$, as well

54 as for other endangered circum-Mediterranean fir forests, such as. A. numidica de Lannoy and $A$.

55 pinsapo marocana Trab. in North Africa.

\section{Abbreviations}

57 AR4: Percentage of all returns above $4 \mathrm{~m}$

58 ARM: Percentage of all returns above mean

59 CC: Canopy Cover

60 CBD: Canopy Bulk Density

$61 \mathrm{CBH}$ : Canopy Base Height

62 FR0.25: Percentage of first returns above $0.25 \mathrm{~m}$

63 FR4: Percentage of first returns above $4 \mathrm{~m}$

64 G: Basal area

65 Ho: Stand height

66 Hv: Vegetation height above $0.25 \mathrm{~m}$ 
67 KIA: Kappa Index of Agreement

68 MMT: Minimum Travel Time

69 RMSE: Root-mean-square error

70 SD: Standard Deviation

71 1. INTRODUCTION

72 Endemic conifer species are more numerous in Mediterranean-type climate regions in the

73 Northern Hemisphere than in the Southern Hemisphere, which has been linked to the selective

74 pressure of cold and/or drought conditions that led to the development of ecophysiological

75 advantages for conifers over angiosperms on oligotrophic soils. Meanwhile, the Mediterranean-

76 type climate regions of South Africa and Southwestern Australia have been more climatically

77 and tectonically stable, which resulted in lower diversity and persistence of ancient lineages of

78 conifers. The Mediterranean Basin has 32 endemic conifer species, accounting for more than

$7925 \%$ of the total conifer flora of 122 species (Rundel, 2019). In particular, the genus Abies Mill.

80 experienced extensive speciation from the late Neogene that gave rise to nine species and one

81 natural hybrid in the Mediterranean Basin (Linares 2011). Past climate changes have led to

82 population migrations, and to shrinkage and fragmentation of ancestral Mediterranean fir

83 populations, further exacerbated by human impacts. This resulted in circum-Mediterranean

84 endemic firs of high paleogeographic interest, since they are established in relict restricted-range

85 populations with relevant vulnerability to global warming effects (Liepelt, et al., 2010).

86 Adaptive management of these forests to protect them from the increasing fire risk is essential

87 for their survival. 
88 Extreme climate events, such as severe droughts, mega-fires, and disease infestations threaten

89

90

91

92

93

94

95

96

97

98 these relict Mediterranean fir populations (Sánchez-Salguero, et al., 2017). It is well known that fire has influenced the landscape and terrestrial life as far back as the beginning of land plants (Bowman, et al., 2009; Pausas \& Keeley, 2009; He, et al., 2012). Although many conifers have developed adaptive traits to live in fire-prone environments, this is not the case for the genus Abies. The firs developed traits appropriate for the humid areas where they thrive, which has rendered them neither resistant (thin bark) nor resilient (recruitment failure in open spaces) to fires (Furyaev, et al., 1983) (Vega, 1999).

Remote sensing is useful for assessment and development of measures for mitigation of the effects of global warming in relict Mediterranean fir forests. Spectral imagery has been employed for the early detection of forest pathogen infestations (Immitzer \& Atzberger, 2014), to estimate evapotranspiration (Dzikiti, et al., 2019), and to study photosynthetic activity (de Sousa, et al., 2017). Meanwhile, 3D point cloud data from laser scanning (LIDAR) have been employed in fire management (Chuvieco \& Kasischke, 2007) and to assess forest volume, biomass (Van Ardt, et al., 2008), and canopy structure (Adamic, et al., 2017) (Mura, et al., 2015). Also, the point cloud can be used for ecological purposes, such as assessing light availability for species distribution modeling (Wüest, et al., 2020) and forest changes in ecotones (Wang, et al., 2020). Airborne LIDAR has shown better suitability for mapping crown and canopy heights (Wang \& Glenn, 2008), although in high density forests the point cloud may not reach the ground, and thus mapping understory vegetation may be inaccurate. However, terrestrial LIDAR has a great potential for estimating shrub and understory biomass, although there are insufficient points for a precise estimation of crown heights when the canopy cover is high (Hilker, et al., 2012). 
111 Mapping fire risk with the support of remote sensing tools is becoming essential for landscape

112 planning in the Mediterranean Basin. High-precision fuel moisture and flammability spatial

113 modeling is achieved by combining satellite and meteorological data into radiative transfer

114 models (Chuvieco, et al., 2006; Yebra, et al., 2018). Burn probability is then assessed through

115 algorithms such as the Minimum Travel Time (MTT) based on the Huygens' principle (Finney,

116 2002). Several studies have previously applied MTT through FlamMap software on fuel spatial

117 models to assess fire risk in Mediterranean-type ecosystems of Greece (Mitsopoulos et al. 2015;

118 Mallinis et al. 2016), Italy (Salis et al. 2015) and Spain (Molina et al., 2017; Alcasena et al.

119 2019). In this last study, fire risk and highly vulnerable areas were mapped for the whole

120 Catalonia region by applying the Scott \& Burgan (2005) fuel model classification on vegetation

121 structure data and running MTT through FlamMap to obtain $150 \mathrm{~m}$ resolution fire scenarios.

122 Alternatively, fire spread from specific ignition events can be forecasted, for example, Salis et al.

123 (2016) used the FARSITE software to derive fire spread simulations for several Euro-

124 Mediterranean countries along an east-west gradient. All these studies agree that accurate and

125 customized fuel models are key for assessing burn probability and fire risk.

126 In this respect, airborne LIDAR technology provides an unprecedented tool for fuel and canopy

127 structure characterization in forest ecosystems. However, several studies highlighted limitations

128 of this technology for accurate understory fuel mapping due to the lack of points reaching the

129 ground (González-Olabarria, et al. 2012; Botequim, et al. 2019). Therefore, LIDAR data need to

130 be implemented in regression models supported by field sampling to eventually characterize the

131 forest structure. For this purpose, hemispherical images are an alternative to traditional field

132 sampling. This technique has been used in forest ecology for more than 50 years, but its

133 widespread adoption was limited due to constraints related to image processing capacity 
134 (Chianucci, 2019). However, technical improvements allowed reducing the time for image

135 processing as well as better image quality acquisition. The widespread proliferation of digital

136 cameras has increased the ease of obtaining and storing hemispherical images, which have

137 become an important tool for fieldwork (Hall, et al., 2017). ForeStereo, a forest inventorying

138 device patented by the Forest Research Centre of the Spanish National Institute for Agriculture

139 and Food Research and Technology (CIFOR-INIA), allows one to obtain stand and tree variables

140 in a cost-effective way by processing pairs of stereoscopic hemispherical images taken at a

141 sampling location (Rodriguez García et al. 2014).

142 Most studies applying LIDAR to circum-Mediterranean fir forests have focused on the most

143 widely distributed Abies alba Mill., whereas those focusing on other species such as the relicts $A$.

144 pinsapo Boiss and A. numidica de Lannoy, which are becoming increasingly vulnerable to global

145 change impacts (Liepelt, et al., 2010), are very scant. Aragón et al. (2019) and Cortés-Molino et

146 al. (2017) studied A. pinsapo Boiss forests using LIDAR, but only for basic tree identification

147 and vegetation landscape analysis, respectively. Now, the combination of remote sensing

148 technology such as laser scanning and proximal sensing (e.g., ForeStereo) can contribute to the

149 monitoring of these relict forests through the acquisition of high-precision stand structure data.

150 Abies pinsapo is restricted to a few areas in southern Spain (A. pinsapo pinsapo) and northern

151 Morocco (Abies pinsapo marocana), totaling less than 8000 ha (Linares, 2008). Forest fires have

152 markedly reduced the size of populations of this fir; in some localities the longest timespan

153 without fires in the period 1817-1997 was just 34 years (Vega, 1999). Thus, fire is considered the

154 most important threat for the conservation and survival of this endangered species (López-

155 Quintanilla et al. 2013). A. pinsapo shows a very low resistance to fire due to its thin bark,

156 despite its relatively low fuel flammability and low fire spread rates in dense stands, due to 
157 sparse understory and relatively humid conditions (Rodríguez y Silva 1996). Additionally, acute

158 symptoms of tree growth decline and forest dieback due to stand stagnation and climate change

159 have already been reported in some populations (Linares \& Carreira, 2009), where Pinus

160 halepensis is increasing in abundance, turning previously pure $A$. pinsapo stands into mixed ones

161 (Linares, et al., 2011a).

162 Our work aimed to combine the use of LIDAR and hemispherical images to study one of the 163 most significant $A$. pinsapo populations, located in a protected area in Málaga (Spain), to assess 164 vulnerability through (i) mapping fire risk and (ii) analyzing canopy structure variability and its 165 possible links to reported declining growth symptoms.

\section{MATERIAL AND METHODS}

\subsection{Study area}

The study location is a steep valley of about 250 ha in area in the municipality of Yunquera, in

Sierra de las Nieves National Park (Fig 1.), in a transition between the upper and lower

Mesomediterranean bioclimatic band. The annual rainfall is around $1500 \mathrm{~mm}$ and the average daily maximum temperature of the warmest month (August) is $33.6{ }^{\circ} \mathrm{C}$ (S.Rivas-Martínez \& Rivas-Saenz, 1996-2020). At the southern border of the valley there is a crest that was the limit

173 of a severe wildfire in 1991 that burned 9000 ha (Narváez, 1991). The eastern part is bordered by

174 crop fields. This, together with summer weather conditions and significant touristic pressure in

175 Sierra de las Nieves National Park, makes the risk of wildfire especially high. This forest belongs

176 to the Paeonio broteroi-Abietetum pinsapo (Asensi \& Rivas-Martínez, 1976) vegetation

177 association composed mainly of pinsapo fir, forming single-species stands in the upper and

178 shaded parts of the valley. The incidence of the root-rot fungus Heterobasidion abietinum 
179 Niemelä \& Korhonen is very high (Linares, et al., 2010). In sunny and low-altitude spots, the 180 forest includes Pinus halepensis and shrubs of Juniperus spp and Cistus spp.

181

182

\subsection{Fieldwork: ForeStereo inventory}

The purpose of the fieldwork was to classify local fuel models and collect forest structure data, mainly canopy cover, and crown and stand heights. The valley was sampled in Spring 2018 with 49 plots of $8 \mathrm{~m}$ radius $\left(50.27 \mathrm{~m}^{2}\right)$, using stereoscopic hemispherical images for obtaining tree metrics such as stand height (Ho), Canopy Base Height (CBH), Canopy Cover (CC), Canopy Bulk Density (CBD) and basal area (G). Shrub cover and height were also assessed by the lineintersect method to support the classification of the fuel models. Each sampling plot was accurately geolocated using a high precision GNSS receiver, supported by an RTK terrestrial station deployed in the upper part of the valley. We assumed a maximum error of $1 \mathrm{~m}$ in each plot, due to the difficulty of getting GNSS coverage in high dense canopy.

Access to field sites was approved by the Andalusian Regional Government (Consejería de Medio Ambiente y Ordenación del Territorio) with the approval code: PNSN/AU/10-2018. Forest inventory was derived using ForeStereo, a device developed by the Forest Research Centre of the Spanish National Institute for Agriculture and Food Research and Technology (INIA-CIFOR). ForeStereo is equipped with two upward-looking fish-eye cameras. At each sampling location three pairs of hemispherical stereoscopic images (Fig. 2) with different exposures are taken. The matching process, compiled in a MatLab® software package, consists of four main steps as detailed in Sánchez-González (2016): (i) a supervised segmentation of tree stems and crowns; (ii) correspondence of features between the two images and photogrammetric retrieval of tree dimensions; (iii) tree variable modeling and (iv) stand variable estimation, which requires correction of instrumental bias and occlusions (Montes, 2019). ForeStereo was used to 
202 estimate tree height, crown base height, crown volume and diameter at breast height (DBH) for

203 each tree, number of stems per hectare and crown cover (CC) and stand basal area (G). Tree

204 metrics from the hemispherical images were compared with airborne LIDAR output data to

205 develop regression models. Thirty-two of the plots were randomly chosen to adjust the models,

206 and the remaining seventeen plots were used to assess the models' predictive capability.

207 Because the geometry of the ForeStereo system and image projections is known, no additional 208 data calibration is needed to carry out photogrammetric retrieval of tree variables. Accuracy of

209 ForeStereo estimated through the Root Mean Squared Error (RMSE) ranges from 0.015 to 0.057

210 m for DBH (Rodríguez-García, et al., 2014; Sánchez-González, et al., 2016), 2.59 to 6.4 m for

211 tree height (Rodríguez-García, et al., 2014; Marino et al. 2018) and 3.1 and $0.6 \mathrm{~m}$ for crown base

212 height and crown diameter respectively (Marino et al, 2018), and $11.6 \mathrm{~m}^{2} / \mathrm{ha}$ for G (Sánchez-

213 González, 2016).

214 With the ForeStereo data we were able to estimate stand height at each plot following the

215 Assmann's criteria (1970), whereas the canopy cover was obtained directly from the

216 hemispherical images, and the Canopy Base Height $(\mathrm{CBH})$ was averaged for each plot. The

217 calculation of the Canopy Bulk Density (CBD) was based on equations reported by Ruiz-

218 Peinado, et al., (2011) for A. pinsapo, in which tree height and stem diameter are used to

219 calculate thin branch and needle biomass. Therefore, CBD is estimated by dividing biomass by

220 crown volume (which is obtained from ForeStereo estimates).

\subsection{LIDAR data.}

222 The LIDAR data were obtained in 2015 by the Spanish National Geographic Institute, through

223 the "Plan Nacional de Ortofotografía Aérea (PNOA)" project. The point cloud density is 0.5 
224 points $\cdot \mathrm{m}^{-2}$. FUSION software was employed for point cloud processing and data extraction

225 (McGaughey \& Carson, 2003). A correlation matrix between ForeStereo tree data and all

226 LIDAR metrics obtained with FUSION was useful to detect which LIDAR metric was most

227 suitable to build the regression models in 32 random plots. We selected the best correlation

228 results $(\mathrm{R}<0.5$, p-value $<0.05)$ to test linear, power and exponential regression models. The

229 models with less root-mean-square error (RMSE) and higher adjusted-R in the remaining 17

230 plots were chosen to predict ForeStereo tree metrics from the LIDAR point cloud. Height break

231 for LIDAR metrics was $4 \mathrm{~m}$, whereas it was $0.25 \mathrm{~m}$ for the total vegetation height to avoid high

232 shrubs influence and ground points, respectively. These two height breaks were tested to inquire

233 which one was the better to fit the models.

234 General canopy structure traits such as canopy cover and height were analyzed from the

235 regression models obtained to detect symptoms of declining growth in this A. pinsapo forest.

236 These variables were chosen because airborne LIDAR can estimate them accurately (Ahmed, et

237 al., 2015; Arumãe \& Lang, 2018). Also, we tested whether canopy bulk density was consistent

238 with the results from this analysis.

\subsection{Fuel models and fire scenarios}

241 To simulate fire risk, we first classified field plots according to the UCO40 fuel models, which

242 use specific criteria and traits appropriate for Mediterranean environments and thus perform

243 better than the widely used Prometheus or Rothermel models (Rodríguez y Silva \& Molina

244 Martínez, 2010; 2012). We identified a total of 6 fuel models across the plots (Table 1, Fig. 3).

245 The UCO4 procedure is based on the fuel models classification of Scott \& Burgan, (2005), but 
246 adapted for southern Spain climate conditions through providing hybrid model types that

247 represent fuel traits and their evolution. Shrub and climate characteristics have shown different

248 behaviors between American and Mediterranean fuel models, so parameters such as fuel load

249 and fuelbed depth must be adjusted (Rodríguez y Silva \& Molina Martínez, 2012).

250 Ecognition ${ }^{\circledR}$ software was used to segment the place of study using the Nearest Neighbor

251 algorithm in an Object-Based Image Analysis (OBIA) (Gao, et al., 2007). To carry out this

252 segmentation, we used the raster layers resulting from the regression models validated previously

253 (CBD, CBH, G, Hv) along with NDVI data from Sentinel-2 images (2015) and terrain models

254 obtained from the LIDAR point cloud (topography, aspect, and slope). Later, a confusion matrix

255 was calculated to evaluate the accuracy of the fuel model classification.

256 The following raster layers generated from the regression models were incorporated: terrain

257 elevation, aspect, slope, $\mathrm{Ho}, \mathrm{CBH}, \mathrm{CBD}, \mathrm{CC}$, and fuel models.

258 The initial fuel moisture file (.FMD) used was based on Scott \& Burgan (2005) suggestions. We

259 assumed a low moisture content (two-third cured) for the fuel more commonly found in north-

260 facing slopes (fuel models M8, HR7 and R4; see Table 1) and very low moisture content (fully

261 cured) for the fuel models more frequently found in south-facing slopes (M3, M9 and HPM4). A

262 Weather Stream file (.WXS) with typical values of circadian change under summer weather

263 conditions in the area was used for dead fuel moisture conditioning (Table 2). This file modifies

264 initial dead fuel moisture based on changes during a given period in weather variables such as

265 temperature, relative humidity, cloud cover and hourly precipitation. Conditioning also implies

266 adjusting initial dead fuel moisture to site factors (elevation, slope, aspect, and canopy cover),

267 based on the corresponding raster layers previously uploaded in FlamMap (Finney, 2006). The 
268 .WXS file was built from meteorological data that are continuously recorded in situ by the

269 University of Jaén (values of temperature, precipitation and relative humidity) and from records

270 of the Spanish Meteorological Agency-AEMET (values of wind and cloud cover). We chose the

271 warmest day of 2014 (available recorded data) for the conditioning period between the 10:00 to

272 19:00 hours without precipitations or any cloud cover. The conditioned fuel moistures at the end

273 of this period were the final fuel moistures used for the simulations.

274 We obtained three different datasets as model outputs: (1) Burn probability based on 200 random

275 ignition points using the MTT algorithm, (2) flame length and (3) flame spread rate, calculated

276 for each cell. The purpose of simulating fire scenarios was to detect vulnerable areas and to

277 assess for conservation planning how exposed the pinsapo forest is to this risk. For this reason,

278 we did not simulate specific events or spotfires using Farsite software. Instead, FlamMap

279 software is more appropriate, because it calculates spread rate and flame length for each

280 landscape cell without a temporal component, and uses MTT to simulate 200 random fires to

281 predict the probability of a point to be burned (Finney, 2006) (González-Olabarria, et al., 2012).

282 The simulations were set under two prevailing wind conditions: west winds (locally called

283 "Ponent") and east winds (called "Levant"), both for a typical speed of $13 \mathrm{~km} \cdot \mathrm{h}^{-1}$.

\section{RESULTS}

We found that the LIDAR metrics that best fit the ForeStereo data were (Table 3): Percentage of first returns above $4 \mathrm{~m}(\mathrm{x})$, Percentage of all returns above $4 \mathrm{~m}(\mathrm{y})$, Percentage of all returns above mean $(\mathrm{z})$ and Percentage of first returns above $0.25 \mathrm{~m}(\mathrm{~d})$. All the significant regression models were obtained with $95 \%$ confidence in the seventeen validation plots. Basal Area $(\mathrm{G})$ 
290 was the only variable with an acceptable fit using a height break of $0.25 \mathrm{~m}$. The rest of the

291 variables were better modeled above $4 \mathrm{~m}$. Canopy Cover (CC) had the best fitting model with an

292 RMSE less than 20\%, while the greatest error was found in modeling the Canopy Base Height

$293(\mathrm{CBH})$ with an RMSE of 83.3\%. This high difference could be due to low point cloud density

294 (minimum 0.5 points $\cdot \mathrm{m}^{-2}$ guaranteed) as well as the fact that airborne LIDAR produces better

295 accuracy for variables related to the top of the canopy (Hilker, et al., 2012), such as canopy cover

296 or canopy height, than variables under the canopy. Results for dominant height were acceptable

297 (RMSE of 0.55), because finding the top of the crowns with ForeStereo in high-density forests

298 can be difficult.

299

300

301

302

303

304

305

306

307

308

309

310

311

312

The error matrix for the fuel model classification using the Nearest Neighbor algorithm shows an overall accuracy of 0.56 and a Kappa Coefficient (KIA) of 0.46 (Table 4). The most frequent fuel model in the study area was M9 (30.5\% of land cover), followed by M3 with 27.4\% and M8 with $23 \%$. In all the fuel models, shrubs play a predominant role in the fire behavior. The least frequent fuel models were HPM4 (7.19\% of land cover; fire behavior mainly controlled by needle litter together with understory shrubs and/or grasses), HR7 (6.12\% of land cover; coniferneedles and branches and other canopy debris play a predominant role) and R4 (5.73\% of land cover; predominance of canopy debris accumulation in fire behavior).

Once the corresponding layers were created based on the regression models, the fuel model classifications and the terrain elevation data (Fig.4), fire simulations under two wind conditions were obtained from FlamMap (Fig. 5). The final landscape file keeps the same pixel resolution of the input data $(10 \mathrm{~m})$. We found higher burn probabilities and spread rate under Levant wind conditions, but similar flame length scenarios under both Levant and Ponient winds. Burn probability was higher under Levant winds, with a mean value of 0.078 , than under Ponent 
313 winds, with a mean value of 0.061 . Fire spread rate showed a mean value of $41.82 \mathrm{~m} \cdot \mathrm{min}^{-1}$

314 under Levant wind conditions, and more than $50 \%$ of the landscape showed spread rates $\geq 50$

$315 \mathrm{~m} \cdot \mathrm{min}^{-1}$. In contrast, Ponent winds resulted in lower fire spread rates (mean value of $33.34 \mathrm{~m}$.

$\left.316 \mathrm{~min}^{-1}\right)$ and a considerably lower fraction of the landscape (36\%) was affected by spread rates $\geq 50$

$317 \mathrm{~m} \cdot \mathrm{min}^{-1}$. Flame length values were similar for the fire simulations under both wind directions.

318 Regarding the canopy structure analysis to detect symptoms of forest decline and dieback, the

319 estimated variables $\mathrm{CBH}$ and $\mathrm{G}$ were not considered due to RMSEs far above $60 \%$. Instead, we

320 use Ho and CC (Fig. 6), as well as CBD, for such assessment. The following results were

321 estimated only in the landscape cells with a vegetation height above $4 \mathrm{~m}$, in order to exclude

322 non-forest patches of shrubs, as well as forest gaps recently opened due to tree mortality (Fig.7).

323 Canopy heights (Ho) ranged from 4 to $18 \mathrm{~m}$, with a mean value of $9.1 \mathrm{~m}$ and a standard

324 deviation (SD) of 3.28. It is remarkable that the mode of canopy heights falls below $5 \mathrm{~m}$ in this

325 forest area not affected by fire since the mid-20th century and under long-term, no management

326 policy. On the other hand, canopy height classes between 7 and $12 \mathrm{~m}$ showed similar frequencies

327 (high equitability). Lastly, canopy heights higher than $15 \mathrm{~m}$ were present, but with rather low

328 frequency.

329 Canopy cover had a mean value of $64.5 \%$ and an SD of 18 . We found low frequencies for values

330 between $0-30 \%(<2 \%$ of the area) because most areas with low CC corresponded to land covered

331 by shrubs with less than $4 \mathrm{~m}$ heights. Almost $25 \%$ of the land showed $\mathrm{CC}$ values above $80 \%$,

332 which means that areas with near to full cover are relatively common. Also, $66 \%$ of the area had

333 a CC of $40-80 \%$. Lastly, CBD mean value was $0.16 \mathrm{~kg} \cdot \mathrm{m}^{-3}$ with a SD of 0.1 . Our results

334 showed a high canopy density because $>60 \%$ of the area had values over $0.1 \mathrm{~kg} \cdot \mathrm{m}^{-3}$ and $>30 \%$

335 was over $0.3 \mathrm{~kg} \cdot \mathrm{m}^{-3}$. 


\section{4. DISCUSSION}

338 Endangered circum-Mediterranean firs are highly vulnerable to climate change effects in the 339 isolated areas where they remain (Sánchez-Salguero, et al., 2017). Abies nebrodensis Mattei is 340 currently the rarest conifer in the European flora, with only 34 mature trees able to reproduce

341 sexually in the wild (Pasta, et al., 2019). The recovery of this species and the protection of the

342 other ones to avoid a similar decrease is an urgent matter that demands the best techniques

343 available to support the traditional field survey.

344 We propose a methodology that combines the use of LIDAR with ForeStereo, UCO40 fuel 345 models, and FlamMap simulations to significantly reduce the effort and time required for 346 fieldwork, increasing the efficiency of the massive data capture required in forest management.

347 The application of this methodology in the study area obtained fire simulations that showed that 348 east wind conditions ("Levant") resulted in worse fire scenarios than west winds ("Ponent") as

349 illustrated in Fig. 5. Spread rate appears to be more influenced by topography and wind

350 conditions (Salis, et al., 2016) than by flame length, which appears to be more influenced by fuel

351 characteristics. Low spread rate and flame length were found in areas with HR7 and R4 models

352 because they correspond to high-density A. pinsapo stands, consistent with the findings of 353 Rodríguez y Silva (1996).

354 Similar results can be found in the Euro-Mediterranean study of Salis et al. (2016), in which the 355 maximum spread rates simulated in the Attica region (Greece), Budoni (Italy), and Fresnedoso 356 de Ibor and Navalmoral (Spain) are between 50-110 $\mathrm{m} \cdot \mathrm{min}^{-1}$. In their study, the worst flame 357 length scenarios are located in Fresnedoso de Ibor (Spain) and Penteli (Greece) with a range 
358 between $25-50 \mathrm{~m}$. They also found a higher spread rate and low flame length mainly in areas

359 with herbaceous vegetation, but also in forest and shrublands in steep mountains exposed to wind

360 (as in our study). In these areas flame length is also higher than in lands with herbaceous

361 vegetation.

362 However, both wind conditions generate two remarkable foci of fire risk, well highlighted in the

363 burn probability map (Fig 5). One is in the north-west part of the valley, on south-facing slopes

$364\left(180^{\circ} \mathrm{N}\right)$ where very dense and tall $(>1.80 \mathrm{~m})$ patches of the shrub Juniperus spp on steep terrain

365 represent ideal conditions for a high fire spread rate $\left(>50 \mathrm{~m} \cdot \mathrm{min}^{-1}\right)$, whereas the flame length will

366 depend more on the wind (Ponent $>15 \mathrm{~m}$, Levant $>30 \mathrm{~m}$ ). It is not surprising that this condition

367 corresponds to the M9 fuel model (Table 1), in which massive shrub formations dominate the

368 fire behavior. The other focus is in the eastern part of the valley, due to the occurrence of fuel

369 models for which fire behavior is mainly determined by the combination of dense shrub cover

370 and very steep slopes $\left(>75^{\circ}\right)$.

371 González-Olabarria (2012) observed a lower fire risk landscape in a carefully managed even-

372 aged forest of Pinus nigra. and P. pinaster, whereas our study corresponds to a non-managed

373 forest of pinsapo firs. This contrast strengthens the argument for the urgent need for adaptive

374 management of these endemic fir forests, abandoning the traditional paradigm of non-

375 management in biological conservation. The kind of prevailing fuel model appears to be

376 determinant for the fire scenarios obtained, and the current "don't touch" management strategy,

377 together with the invasion by shrubs into forest mortality gaps, seem to promote high fire risk

378 fuel models in the area. 
379 The distribution of canopy structure features depicted in Fig. 6 highlights: (i) that the most

380 frequent stand height barely reaches $5 \mathrm{~m}$, the mean value is just $9.1 \mathrm{~m}$ and figures higher than $12-$

$38115 \mathrm{~m}$ are rare despite the fact that $A$. pinsapo can reach up to $30-35 \mathrm{~m}$ in height (López-

382 Quintanilla, et al., 2013); (ii) that canopy cover has an average value of $64.5 \%$, well below the

383 full-cover criterion under a "set aside" and "no management" strategy since the late 1960s, and

384 patches with $90 \%-100 \%$ cover account for less than $10 \%$ of the whole area; and (iii) that there is

385 an overall very high variability for both stand height and canopy cover values across the

386 landscape, with a relatively high evenness in both variable distributions, especially regarding tree

387 height. All these results indicate a lack of old-growth stands in the study area, and the

388 predominance of secondary forests, which is consistent with previous studies based on field

389 surveys (Linares, et al, 2011b; 2013).

390 We found considerably high values of canopy density (CBD: Fig. 4), which can increase the risk 391 of severe crown fires (Arellano 2017). These canopy density values in a well below full-cover

392 area, together with low Ho suggests two possible explanations: (i) the high CBD values

393 correspond to full-cover patches with older stands where gaps are still not open and/or (ii) shrub

394 strata are increasing their height above $4 \mathrm{~m}$, interlocking with the canopy. Both are compatible

395 with different phases of forest decline and the gap opening process.

396 The low stand height values we found, even in the patches with older stands and high cover

397 values, could indicate symptoms of stand stagnation in such patches. A multi-temporal

398 comparison (1957-2007) and fractal analysis of digital panchromatic aerial photographs of the

399 same area (Linares, et al. 2006; 2009), revealed a process of simultaneous stand densification

400 and expansion of $A$. pinsapo at the landscape level in the last decades. This is a consequence of

401 strict protection since the 1960s of an area mostly covered at the time by bare soils and open 
402 scrublands, with a few sparsely distributed and small stands and isolated trees of $A$. pinsapo.

403 Increasing competition due to the densification of these regenerating even-aged stands led to

404 stand stagnation in the 1980s, which acted as a predisposing factor for the climate change-

405 induced forest decline symptoms reported since 1994-95, associated with a series of very intense

406 drought spells that acted as an inciting factor (Linares \& Carreira, 2009). Finally, tree growth

407 decline and loss of vigor led to the expansion of the root-rot fungus pathogen Heterobasidion

408 abietinum, (Linares, et al., 2010), which acted as a contributing factor (Manion, 1981) causing

409 widespread mortality and extensive formation of forest-gaps in the last two decades $(>1 / 3$ of the

410 previous basal area lost). This multifactorial forest decline and dieback process increases the

411 production of HR7 and R4 fuel models, as shown in Fig. 7. Under the prevalent "no-

412 management" policy, these new open areas are, eventually, being invaded by dense shrubs, as

413 supported by our LIDAR and ForeStereo data. This increases their importance in the fire

414 behavior and promotes fuel models with high fire spread rate such as the UCO M9 fuel type. The

415 fuel model classification revealed a remarkable contribution of M9 (Fig. 4), covering 30.5\% of

416 the study area. This suggests that shrub invasion is taking place and is already in an advanced

417 phase. Also, the CBD values point to a high exposure to crown fires (Arellano, et al., 2017) and

418 could explain the forecasted high flame length in some areas.

419 As explained in the Introduction section, fire intensity in pinsapo forests is known to be low, but

420 the above-mentioned current invasion into the mortality gaps by the surrounding dense shrubs

421 could invert this tendency.

422 However, it must be highlighted that the efficacy of employing fire simulations in risk

423 management strongly depends on input data of high accuracy and precision, due to the complex

424 heterogeneity of forest landscapes (Rodríguez y Silva \& Molina-Martínez, 2012). Although we 
425 precisely determined shrub composition and structure in a set of training field plots, the low

426 LIDAR point cloud density available hindered reliable mapping of understory vegetation, which

427 thus may restrict the accuracy of the obtained fire risk simulations. The combined use of LIDAR,

428 both terrestrial and airborne, could be the best option to map fuel models and canopy data such

429 as Canopy Base Height and Canopy Bulk Density, for increased accuracy. Nevertheless,

430 ForeStereo was shown to be a useful alternative to terrestrial LIDAR for calculating stand

431 structure. Our study attempts to set a precedent as the first approach to fire risk analysis in Abies

432 pinsapo forests using LIDAR. Also, it demonstrates the significant potential of this method for

433 study of the ecological structure of populations of endangered fir species, and to broaden the

434 understanding of their conservation status. Most of the current work with LIDAR data focuses on

435 forests with commercial interest, and few studies have employed this technology to understand

436 the structure of the populations of endangered species forests and their vulnerability to fire risk.

\section{CONCLUSIONS}

441 Our results show a high fire risk for the largest remaining continuous forest of the relict and

442 endangered $A$. pinsapo tree species. Such risk, especially under east wind conditions (Levant), was found to be associated with a remarkable presence of shrub-dominated fuel models (M9).

444 Using aerial LIDAR and ForeStereo data to assess stand structure spatial variability in the area, 445 we found symptoms of stand stagnation and forest decline under the current no-management 446 conservation policy. This process together with climate change trends triggers the formation of 
447 mortality-gaps that are eventually invaded by shrubs, increasing the production of the M9 fuel

448 model, which in turn worsen fire risk. These findings stress the need for proactive adaptive

449 management of $A$. pinsapo forests, including: (i) the creation of bare patches through shrub

450 clearing, (ii) a reinforcement of the firewalls in the west part of the valley and (iii) promotion of

451 grazing and trampling levels by wild ungulates (or domestic livestock if they were insufficient)

452 to reduce shrub fuel load without compromising $A$. pinsapo. We also support the efficacy of

453 thinning treatments for canopy structural diversity enhancement as an essential tool to avoid

454 stand stagnation (Linares et al., 2009a), (Linares, et al., 2009b), (Lechuga, et al., 2017; 2019) and

455 high CBD values, to reduce the probability of crown fires and thus increase resilience to

456 wildfires (Koontz, et al, 2020), as well as to reduce climate change-induced tree mortality

457 (Linares, et al., 2009a).

458 The importance of the A.pinsapo populations in Sierra de las Nieves is one of the main reasons

459 that inspired Spanish national policy to upgrade this protected area into a National Park.

460 Although the models obtained have low accuracy due to technical limitations, our study provides

461 a preliminary estimate, a first step to assess pinsapo forest risk factors using remote and proximal

462 sensing as essential tools to support conservation management. These methods can also be

463 extended to the monitoring of other endangered Western Mediterranean relict fir forests such as

464 those of $A$. numidica and A. pinsapo marocana in North Africa and can be implemented in their

465 conservation strategies.

466

467 6. ACKNOWLEDGMENTS 
468 We thank Víctor Lechuga and Antonio Román (University of Jaén), for assistance during

469 fieldwork, Fernando Montes Pita, (INIA-CIFOR) for facilitating the ForeStereo device, which

470 was essential for the fieldwork, and José Luis López Quintanilla (coordinator of the regional

471 government plan for the restoration and conservation of Abies pinsapo habitats) for providing

472 relevant information about the study area and species.

473 Dr. Eric C. Henry kindly revised the English style and usage.

474 This research did not receive any specific grant from funding agencies in the public, commercial 475 or not-for-profit sectors.

476

\section{7. REFERENCES}

Adamic, M., Diaci, J., Rozman, A., \& Hladnik, D. (2017). Long-term use of uneven-aged silviculture in mixed mountain Dinaric forests: A comparison of old-growth and managed stands. Forestry, 90(2), 279-291. https://doi.org/10.1093/forestry/cpw052

Ahmed, O. S., E., F. S., Wulder, M. A., \& White, J. C. (2015). Characterizing stand-level forest canopy cover and height using Landsat time series, samples of airborne LIDAR, and the Random Forest algorithm. ISPRS Journal of Photogrammetry and Remote Sensing, 101,

Alcasena, F. J., Ager, A. A., Bailey, J. D., Pineda, N., Vega-García, C. (2019). Towards a comprehensive wildfire management strategy for Mediterranean areas: Framework 89-101. https://doi.org/10.1016/j.isprsjprs.2014.11.007 development and implementation in Catalonia, Spain. Journal of Environmental Management. 231 303-320 https://doi.org/10.1016/j.jenvman.2018.10.027 
490

491

492

493

494

495

496

497

498

499

500

501

502

503

504

505

506

507

508

509

510

511

Anderson, H.E. (1982). Aids to determining fuel models for estimating fire behavior. General Technical Report INT-122, United States Department of Agriculture, Forest Service, Intermountain Forest and Range Experiment Station, Ogden, UT. 26 pAragón, J. F., Navarro Cerrillo, R., \& Mesas Carrascosa, F. (2019). Validación de un paratrike como plataforma para la captación de imágenes de alta resolución en formaciones de Abies pinsapo Boiss. Cuadernos de la Sociedad Española de Ciencias Forestales, 45(2), 171 204. https://doi.org/10.31167/csecfv5i45.19875

Arellano Pérez, S., González Álvarez, J. G., Vega Hidalgo, J. A., Ruiz González, A. D. (2017) Modelos de estimación de la distribución vertical de combustibles finos de copas en masas de pinar a partir de datos del IV Inventario Forestal Nacional. $7^{\circ}$ Congreso Forestal Español. Plasencia (Cáceres, Spain).

Arumãe, T., \& Lang, M. (2018). Estimation of canopy cover in dense mixed-species forests using airborne lidar data. European Journal of Remote Sensing, 51(1), 132-141. https://doi.org/10.1080/22797254.2017.1411169

Asensi, A., \& Rivas-Martínez, S. (1976). Contribución al conocimiento fitosociológico de los pinsapares de la Serranía de Ronda. Anales Instituto Botánico Cavanilles, 33, 239-247.

Assman, E. (1970). The principles of forest yield study. Pergamon Press, 506. ISBN: 9781483150932

Botequim, B., Fernandes, P. M., Borges, J. G., González-Ferreiro, E., Guerra-Hernández, J. (2019). Improving silvicultural practices for Mediterranean forests through fire behavior modeling using LiDAR-derived canopy fuel characteristics. International Journal of Wildland Fire. 28, 823-839 https://doi.org/10.1071/WF19001 
512 Bowman, D., Balch, J. K., Artaxa, P., Bond, W. J., Carlson, J. M., Cochrane, M. A., D'Antonio

513 C. S., DeFries R. (2009). Fire in the earth system. Science, 324, 481-484.

514 https://doi.org/10.1126/science.1163886 Chianucci, F. (2019). An overview of in situ

515 digital photographic approaches to estimate forest canopy attributes. Canadian Journal of

$516 \quad$ Forest Research. https://doi.org/10.1139/cjfr-2019-0055

517 Chuvieco, E., Riaño, D., Danson, F. M., Martin, P. (2006). Use of a radiative transfer model to

518 simulate the postfire spectral response to burn severity. Journal of Geophysical Research:

519 Biogeosciences, $111(\mathrm{G} 4)$.

520 Chuvieco, E., \& Kasischke, E. S. (2007). Remote sensing information for fire management and

521 fire effects assessment. Journal of Geophysical Research: Biogeosciences, 112 (G1).

522 https://doi.org/10.1029/2006JG000230

523 Cortés-Molino, A., Melero Jiménez, I. J., Fernández Luque, I., Flores-Moya, A., \& Salvo Tierra,

524

525

526

527

528

529

530

531

532
A. E. (2017). Análisis de la estructura de la vegetación del poljé de la Nava de los

Pinsapos mediante tecnología LIDAR. Murcia: Asociación Española de Teledetección. ISBN: 978-84-9048-650-4

de Sousa, C. H., Hilker, T., Waring, R., de Moura, Y. M., \& Lyapustin, A. (2017). Progress in remote sensing of photosynthetic activity over the Amazon Basin. Remote Sensing (Basel), 9(1). https://doi.org/ 10.3390/rs9010048

Dzikiti, S., Jovanovic, N. Z., Bugan, R. D., Majozi, N. P., Nickless, A., Cho, M. A., . . Pienaar, H. H. (2019). Comparison of two remote sensing models for estimating evapotranspiration: algorithm evaluation and application in seasonally arid ecosystems in 
533

534

535

536

537

538

539

540

541

542

543

544

545

546

547

548

549

550

551

South Africa. Journal of Arid Land, 11, 495-512. https://doi.org/10.1007/s40333-019$\underline{0098-2}$

Finney M (2002) Fire growth using minimum travel time methods. Canadian Journal of Forest Research 32:1420-1424

Finney, M. A. (2006). An overview of FlamMap fire modeling capabilities. USDA Forest Service Proceedings, 41, 213-220.

Furyaev, V., Wein, W. R., \& MacLean, D. A. (1983). Fire influences in Abies-dominated forests. In R. W. MacLean (Ed.), The role of fire in Northern Circumpolar Ecosystems (pp. 221-234). John Wiley \& Sons Ltd. Chinchester

Gao, Y., Mas, J. M., Niemeyer, I., Marpu, P. R., \& Palacio, J. L. (2007). Object-based image analysis for mapping land-cover in a forest area. Enschede: International Symposium for Spatial Date Quality (ISSDQ).

González-Olabarria, J. R., Rodríguez, F., Fernández-Landa, A., \& Yudego-Mola, B. (2012). Mapping fire risk in the Model Forest of Urbión (Spain) based on airborne LIDAR measurements. Forest Ecology and Management, 282, 149-156. https://doi.org/10.1016/j.foreco.2012.06.056

Hall, R. J., Fournier, A. F., \& Rich, P. (2017). Introduction. In Hemispherical Photography in Forest Science: Theory, Methods, and Applications (Vol. 28, p. 313). Springer. ISBN 978-94-024-1098-3. 
552 He, T., Pausas, J. G., Belcher, C. M., Schwilk, W. D., \& B., L. B. (2012). Fire adapted traits of

553 Pinus arose in the fiery Cretaceous. New Phytologist, 194, 751-759.

$554 \quad$ https://doi.org/10.1111/j.1469-8137.2012.04079.x

555 Hilker, T., N., C. C., Newnham, G. J., van Leeuwen, M., Wulder, M. A., Stewart, J., \& Culvenor,

556 D. S. (2012). Comparison of terrestrial and airborne LIDAR in describing stand structure

557 of a thinned lodgepole pine forest. Journal of Forestry, 110(2), 97-104.

$558 \quad$ https://doi.org/10.5849/jof.11-003

559 Immitzer, M., \& Atzberger, C. (2014). Early detection of bark beetle infestation in Norway

560 Spruce (Picea Abies, L.) using WorldView-2 Data. Photogrammetrie - Fernerkundung -

561 Geoinformation, 2014(5), 351-367. https://doi.org/10.1127/1432-8364/2014/0229

562 Lechuga, V; V. Carraro, B. Viñegla, J.A. Carreira, J.C. Linares. (2017). Managing droughtsensitive forests under global change. Low competition enhances long-term growth and water uptake in Abies pinsapo. Forest Ecology and Management 406: 72-82. https://doi.org/10.1016/j.foreco.2017.10.017

566

567

568

569

570

571

572

573
Lechuga, V.; V. Carraro, B. Viñegla, J.A. Carreira, J.C. Linares. (2019). Carbon limitation and drought sensitivity at contrasting elevation and competition of Abies pinsapo Forests. Does experimental thinning enhance water supply and carbohydrates?. Forests 10 (12): 1132 (17 pp.). https://doi.org/10.3390/f10121132

Liepelt, S., Mayland-Quellhorst, E., Lahme, M., \& Ziegenhagen, B. (2010). Contrasting geographical patterns of ancient and modern genetic lineages in Mediterranean Abies species. Plant Systematics and Evolution, 284(3-4), 141-151. https://doi.org/10.1007/s00606-009-0247-8 
574 Linares J.C., F.J. Esteban, B. Viñegla \& J.A. Carreira. (2006). A computational analysis of multi575 temporal vegetation changes using the fractal dimension spectrum. Harmonic and Fractal $576 \quad$ Image Analysis, e-journal 1: 97-100.

577

578 Linares, J. C. (2008). Effects of global change overpopulation dynamic and ecophysiology of 579 Abies pinsapo Boiss relictian forests. Ph.D. Thesis. University of Jaén.

580 Linares, JC; Camarero, JJ; Carreira, JA. (2009). Interacting effects of changes in climate and forest 581 cover on mortality and growth of the southernmost European fir forests. Global Ecology and 582 Biogeography 18 (4): 485-497.

583

584

585

586

587

588

589

590

591

592

593

594 595
Linares, J. C., \& Carreira, J. A. (2009). Temperate-like stand dynamics in relict Mediterraneanfir (Abies pinsapo, Boiss.) forests from southern Spain. Annals of Forest Sciences, 66. https://doi.org/10.1051/forest/2009040

Linares, J. C., Camarero, J. J., \& Carreira, J. A. (2009a). Plastics responses of Abies pinsapo xylogenesis to drought and competition. Tree Physiology. https://doi.org/10.1093/treephys/tpp084

Linares, J. C., Delgado-Huertas, A., Camarero, J. J., Merino, J., \& Carreira, ,. J. (2009b). Competition and drought limit the response of water-use efficiency to rising atmospheric carbon dioxide in the Mediterranean fir Abies pinsapo. Global Change Ecology, 161, 611-624. https://doi.org/10.1007/s00442-009-1409-7

Linares, J. C., Camarero, J. J., Bowker, M. A., Ochoa, V., \& Carreira, J. A. (2010). Standstructural effects on Heterobasidion abietinum-related mortality following drought events 
596

597

598

599

600

601

602

603

604

605

606

607

608

609

610

611

612

613

614

615

616 in Abies pinsapo. Global Change Ecology, 164, 1107-11019. https://doi.org/10.1007/s00442-010-1770-6

Linares J.C. (2011). Biogeography and evolution of Abies (Pinaceae) in the Mediterranean Basin. The roles of long-term climatic changes and glacial refugia. Journal of Biogeography 38: 619-630. https://doi.org/10.1111/j.1365-2699.2010.02458.x

Linares, J. C.; Carreira, JA.; Ochoa, V. (2011b). Human impacts drive forest structure and diversity. Insights from Mediterranean mountain forest dominated by Abies pinsapo (Boiss.) European Journal of Forest Research 130 (4): 533-542.

Linares, J. C., Delgado-Huertas, A., \& Carreira, J. A. (2011a). Climatic trends and different drought adaptive capacity and vulnerability in a mixed Abies pinsapo- Pinus halepensis forest. Climate Change, 105, 67-90. https://doi.org/10.1007/s10584-010-9878-6

Linares J.C., J. J. Camarero, A. Delgado-Huertas \& J.A. Carreira. (2013). Efectos de los cambios de clima y usos del territorio sobre la dinámica y el crecimiento de los bosques de Abies pinsapo en las últimas décadas. In: López-Quintanilla, J., R.M. Navarro, J.A. Carreira, M. Coca \& C. Rodríguez, Los pinsapares (Abies pinsapo Boiss.) en Andalucía: Conservación y sostenibilidad en el siglo XXI., capítulo 24, pp. 401-412. Junta de Andalucía y Universidad de Córdoba. ISBN: 978-84-92807-74-1, 978-84-9927-137-8

López-Quintanilla, J.; Navarro, R.M., J.A. Carreira, M. Coca \& C. Rodríguez (eds.) (2013). Los pinsapares (Abies pinsapo Boiss.) en Andalucía: Conservación y sostenibilidad en el siglo XXI. 576 pp. Junta de Andalucía y Universidad de Córdoba. ISBN: 978-84-9280774-1, 978-84-9927-137-8 
617 Mallinis, G., Mitsopoulos, I., Beltran, E., Goldamer, J. G. (2016). Assessing Wildfire Risk in 618 Cultural Heritage Properties Using High Spatial and Temporal Resolution Satellite Imagery and Spatially Explicit Fire Simulations: The Case of Holy Mount Athos, Greece.

Manion P (1981) Tree Disease Concepts. Prentice-Hall, Englewood Cliffs, NJ

Marino, E., Montesa, F., Tomé, J.L., Navarro, J.A., Hernando, C. 2018. Vertical forest structure analysis for wildfire prevention: Comparing airborne laser scanning data and stereoscopic hemispherical images. Int J Appl Earth Obs Geoinformation 73: 438-449

McGaughey, R. J., \& Carson, W. W. (2003). Fusing LIDAR data, photographs and other data using 2D, and 3D visualization techniques. Proceedings of Terrain Data: Applications and Visualization-Making the Connection, 16-24.

Mitsopoulos, I., Mallinis, G., Arianoutsu, M. (2015) Wildfire risk assessment in a typical Mediterranean wildland-urban interface of Greece. Environmental Management. 55:900915 https://doi:10.1007/s00267-014-0432-6

Molina, J. R., Rodríguez y Silva, F., Herrera, M. A. (2017) Economic vulnerability of fire-prone landscapes in protected natural areas: application in a Mediterranean Natural Park. European Journal of Forest Research 136:609-624. https://doi:10.1007/s10342-017-1059yMontes, F., Rubio-Cuadrado, Á., Sánchez-González, M. de la O., Aulló-Maestro, I., Field Sampling with ForeStereo. Photogrammetric Engineering and Remote Sensing, 85(7), 493-508. https://doi.org/10.14358/PERS.85.7.493

Mura, M., McRoberts, R. E., Chirice, G., \& Marchetti, M. (2015). Estimating and mapping forest 
639

640

641

642

643

644

645

646

647

648

649

650

651

652

653

654

655

656

657

658

structural diversity using airborne laser scanning data. Remote Sensing of Environment, 170, 133-142. https://doi.org/10.1016/j.rse.2015.09.016

Narváez, D. (1991, August 13). Extinguido el incendio que ha arrasado 9.000 hectáreas en la Serranía de Ronda. El País.

Pasta, S., Sala, G., La Mantia, T., Bondi, C., Tinner, W. (2019). The past distribution of Abies nebrodensis (Lojac.) Mattei: results of a multidisciplinary study. Vegetation History and Archaeobotany. https://doi.org/10.1007/s00334-019-00747-0

Pausas, J. G., \& Keeley, J. E. (2009). A burning story: The role of fire in the history of life. BioScience, 59(7), 593-601. https://doi.org/10.1525/bio.2009.59.7.10

Rivas-Martínez, S. \& Rivas-Sáenz, S. (1996-2020). Worldwide Bioclimatic Classification System. Phytosociological Research Center, Spain. http://www.globalbioclimatics.org

Rodríguez y Silva, F. (1996) Protección y defensa de los pinsapares ante los incendios forestales. Jornadas técnicas internacionales sobre recuperación de pinsapares, Grazalema, 12, 13 y 14 de diciembre de 1996.

Rodríguez y Silva, F., \& Molina Martínez, J. R. (2010). Manual técnico para la modelización de la combustibilidad asociada a los ecosistemas forestales mediterráneos. Córdoba: Forest Fire Lab Defence, University of Córdoba (Spain). ISBN: 978-84-693-2151-1.

Rodríguez y Silva, F., \& Molina-Martínez, J. (2012). Modeling Mediterranean forest fuels by integrating field data and mapping tools. European Journal of Forest Research, 131, 571582. https://doi.org/10.1007/s10342-011-0532-2 
659 Rodríguez-García, C., Montes, F., Ruiz, F., Cañellas, I., \& Pita, P. (2014). Stem mapping and 660 estimating standing volume from stereoscopic hemispherical images. European Journal 661 of Forest Research, 133, 895-904. https://doi.org/10.1007/s10342-014-0806-6

662

663

664

665

666

667

668

669

670

671

672

673

674

675

676

677

678

679

680

Ruiz-Peinado, R., del Río, M., \& Montero, G. (2011). New models for estimating the carbon sink capacity of Spanish softwood species. Forest Systems, I(20), 176-188. https://doi.org/10.5424/fs/2011201-11643

Rundel, P. W. (2019). A Neogene Heritage: Conifer Distributions and Endemism in Mediterranean-Climate Ecosystems. Frontiers in Ecology and Evolution, 7. https://doi.org/10.3389/fevo.2019.00364

Salis, M., Ager, A. A., Alcasena, F. J., Arca, B., Finney, M. A., Pellizzaro, G., Spano, D. (2015) Analyzing seasonal patterns of wildfire exposure factors in Sardinia, Italy. Environ Monit Assess 187:4175 DOI 10.1007/s10661-014-4175-x

Salis, M., Arca, B., Alcasena, F., Arianoutsou, M., Bacciu, V., Duce, P., Duguy, B., Koutsias, N., Mallinis, G., Mitsopoulos, I., Moreno, J. M., Pérez, J. R., Urbieta, I.R., Xystrakis, F., Zavala, G., Spano, D. (2016). Predicting wildfire spread and behavior in Mediterranean landscapes. International Journal of Wildland Fire 25, 1015-1032 http://dx.doi.org/10.1071/WF15081Sánchez-González, M., Cabrera, M., Herrera, P. J., Vallejo, R., Cañellas, I., \& Montes, F. (2016). Basal area and diameter distribution estimation using stereoscopic hemispherical images. Photogrammetric Engineering \& Remote sensing, 82, 605-616. https://doi.org/10.14358/PERS.82.8.605

Sánchez-Salguero, R., Camarero, J. J., Carrer, M., Gutiérrez, E. A., Andreu-Hayles, L., Hevia, A., Koutavas, A., Martínez-Sancho, E., Nola, P., Papadopulos, A., Pasho, E., Toromani, 
681

682

683

684

685

686

687

688

689

690

691

692

693

694

695

696

697

698

699

700

E., Carreira, J. A. and Linares, J. C. (2017). Climate extremes and predicted warming threaten Mediterranean Holocene firs forests refugia. Proceedings of the National Academy of Sciences. https://doi.org/ 10.1073/pnas.1708109114

Scott, Joe H.; Burgan, Robert E. 2005. Standard fire behavior fuel models: a comprehensive set for use with Rothermel's surface fire spread model. Gen. Tech. Rep. RMRS-GTR-153. Fort Collins, CO: U.S. Department of Agriculture, Forest Service, Rocky Mountain Research Station. 72 p.

Van Ardt, J. A., Wynne, R., \& Scrivani, J. (2008). Lidar-based mapping of forest volume and biomass by taxonomic group using structurally homogenous segments. Photogrammetric Engineering and Remote Sensing, 75(8), 1033-1044. https://doi.org/10.14358/PERS.74.8.1033

Vega Hidalgo, J. A. (1999). Historia del fuego de Pinus pinaster y Abies pinsapo en la carta norte de Sierra Bermeja (Málaga): 1817-1997. Incendios históricos, una aproximación multidisciplinar. Baeza. UNIA.

Wang C., \&. N., Glenn (2008). A linear regression method for tree canopy height estimation using airborne lidar data. Canadian Journal of Remote Sensing, 34. https://doi.org/10.5589/m08-043

Wang, Z., Ginzler, C., \& Waser, L. T. (2020). Assessing structural changes at the forest edge using kernel density estimation. Forest Ecology and Management, 456, 117639. https://doi:10.1016/j.foreco.2019.117639 
701 Wüest, R. O., Bergamini, A., Bollmann, K., \& Baltensweiler, A. (2020). LiDAR data as a proxy

702 for light availability improve distribution modeling of woody species. Forest Ecology

703 and Management, 456, 117644. https://doi:10.1016/j.foreco.2019.117644 moisture content and flammability monitoring methodology for continental Australia

706 based on optical remote sensing. Remote Sensing of Environment 212 (2018) 260-272

707 https://doi.org/10.1016/j.rse.2018.04.053 


\section{Figure 1}

Study area location, in the National Park of Sierra de las Nieves (Andalusia, Spain)

Forty-nine plots were used in the field-based sampling for calibration purposes using

ForeStereo device. Yellow points are training plots, red ones are validation plots. White arrows indicate the firewalls opened on the area. Base map and data from OpenStreetMap and OpenStreetMap Foundation. 


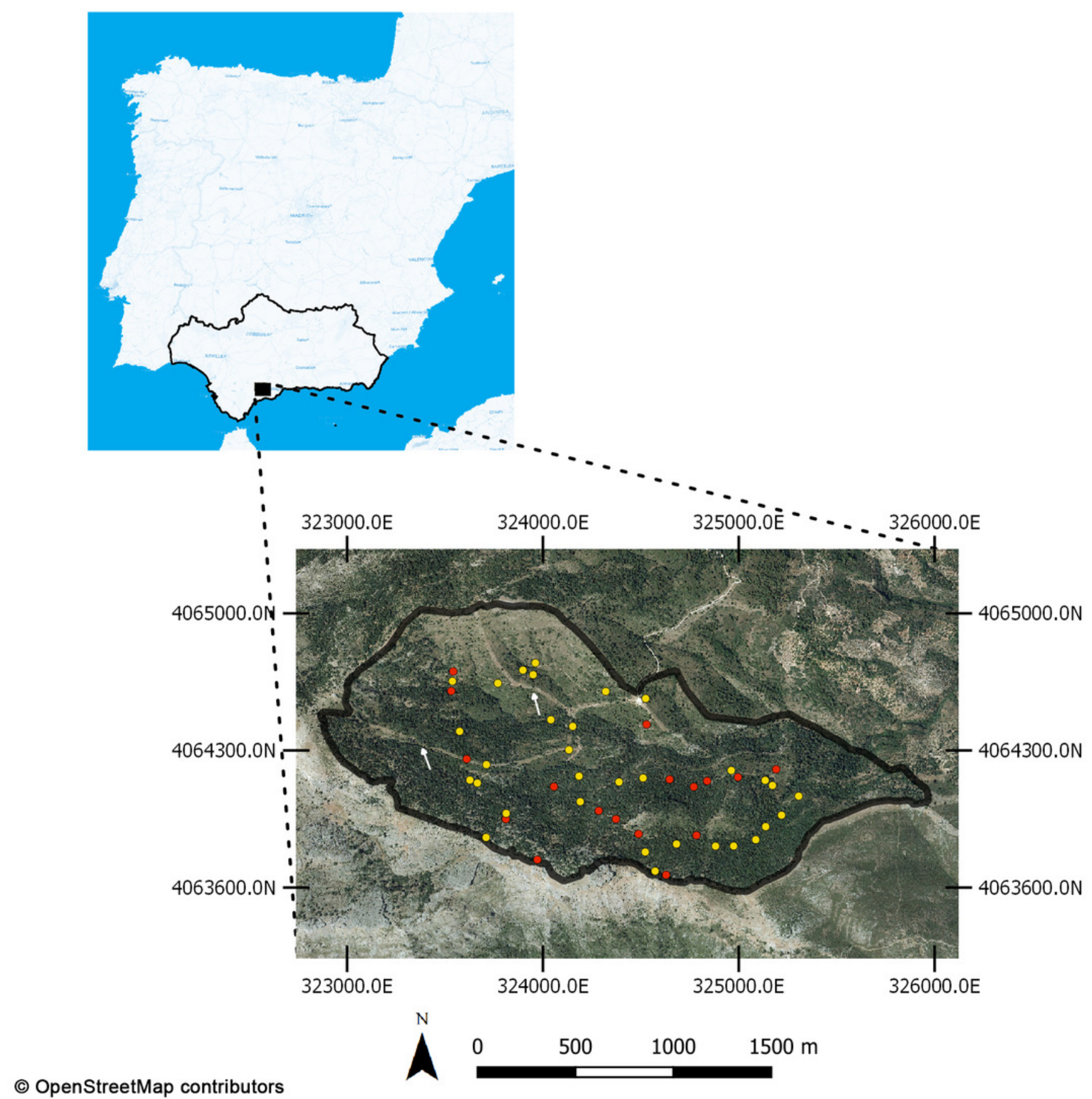




\section{Figure 2}

Example of hemispherical pair images obtained with ForeStereo to characterize forest stand canopy structure at the field sampling plots

A and B are both stereoscopic images obtained at the same time in each plot.

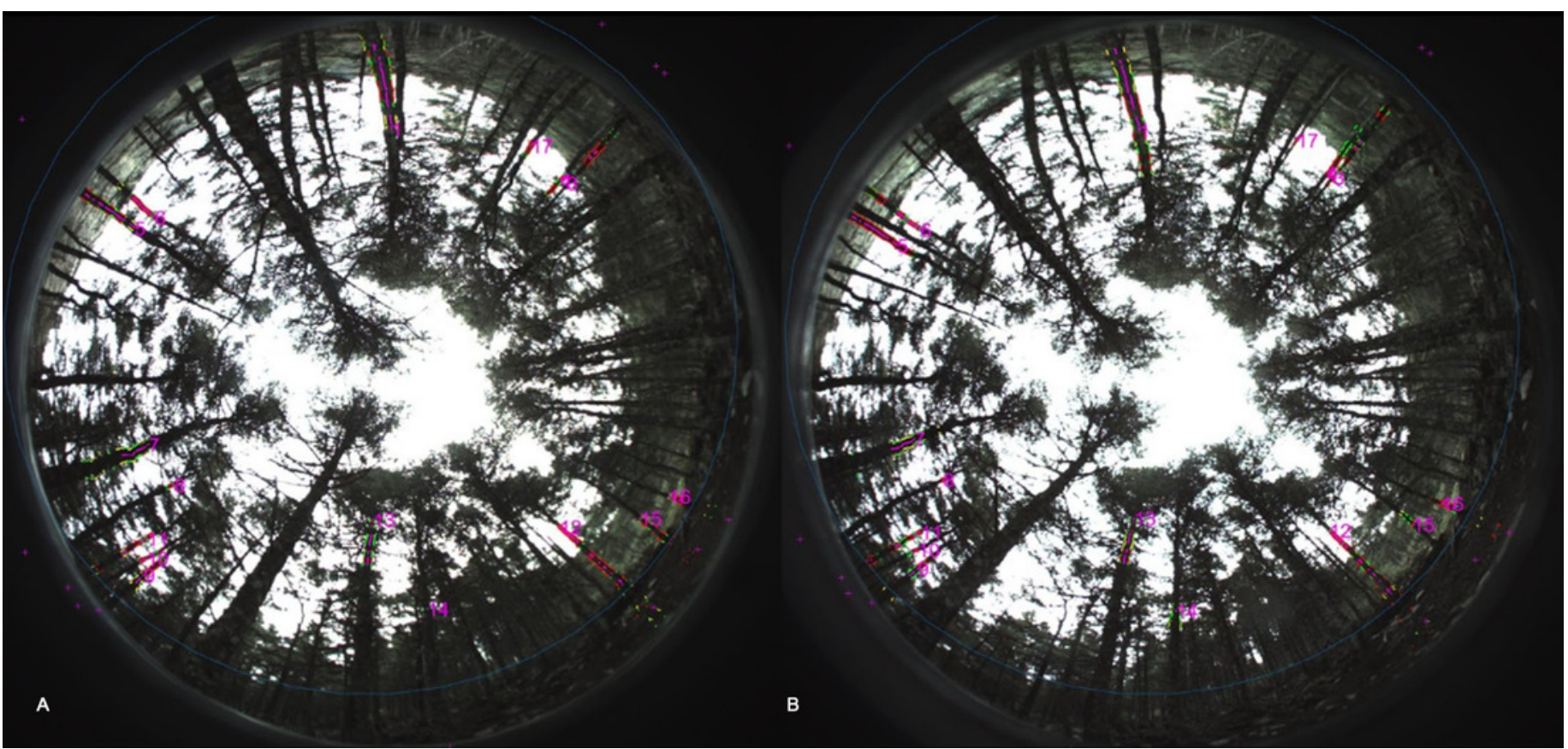




\section{Figure 3}

Example of the six fuel models identified in the plots based on Rodríguez y Silva \& Molina Martínez (2010) handbook

(A) R4 model: Predominance of canopy debris accumulation (B) HR7 model: Predominance of pine needle with branches (C) HPM4 model: Pine-needle with shrubs and grass (D) M3 model: Predominance of shrubs with a fuel bed close to $1 \mathrm{~m}$ (E) M8 model: Predominance of shrubs with grass with a fuel bed of $120 \mathrm{~m}$. (F) M9 model: Predominance of thick shrubs with a fuel bed over $175 \mathrm{~m}$. 

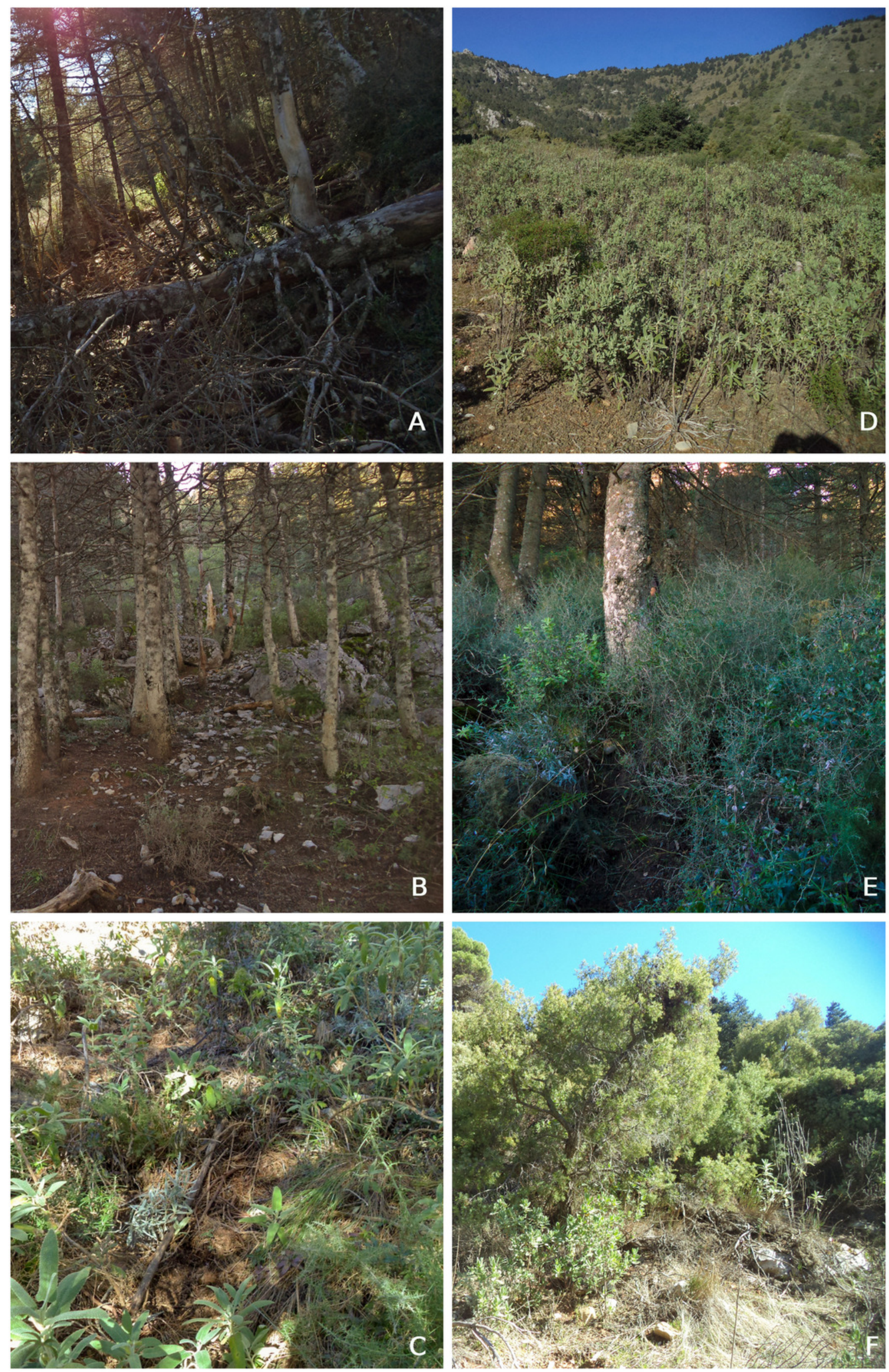
Figure 4

LIDAR raster layers produced to run Flammap

(A) Canopy cover (\%). (B) Stand height (m). (C) CBH (m). (D) CBD $\left(\mathrm{Kg} / \mathrm{m}^{3}\right)$. (E) Fuel models.

(F) Aspect (o). (G) Elevation (m) (H) Slope (\%). 


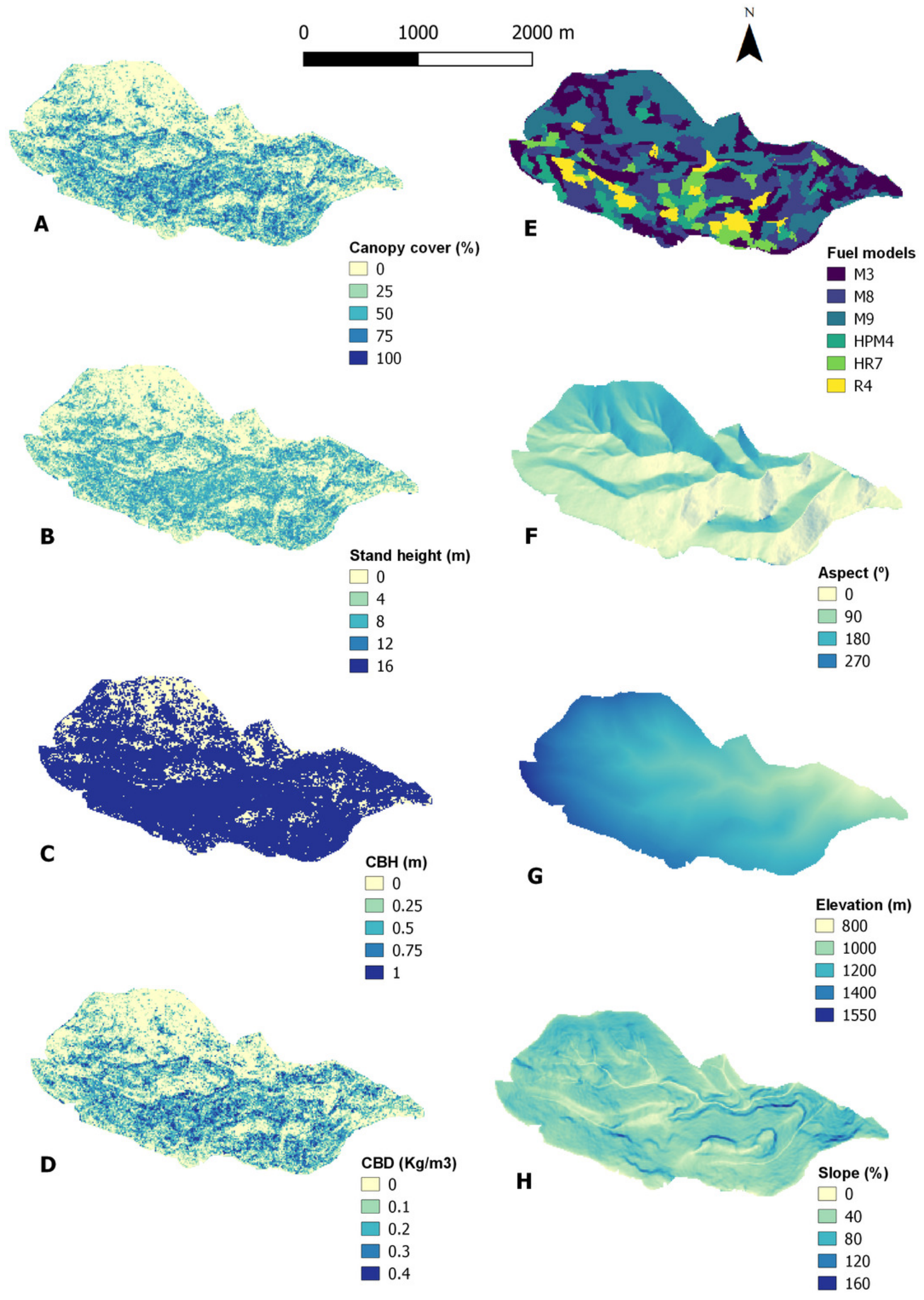




\section{Figure 5}

Fire simulations obtained from Flammap for Ponent wind (West) and Levant wind (East) conditions

(A) Burn probability in Ponent wind. (B) Spread rate in Ponent wind ( $\mathrm{m} / \mathrm{min}$ ). (C) Flame length in Ponent wind (m). (D) Burn probability in Levant wind. (E) Spread rate in Levant wind (m/min). (F) Flame length in Ponent wind (m).

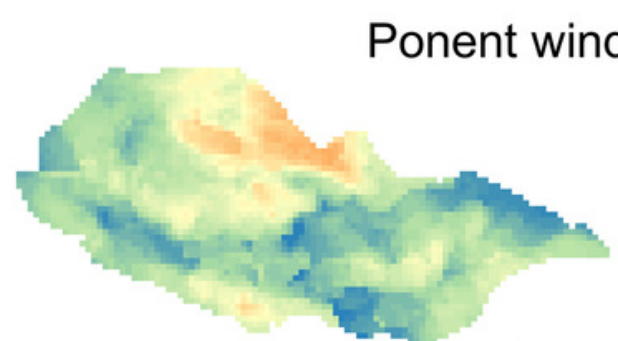

A

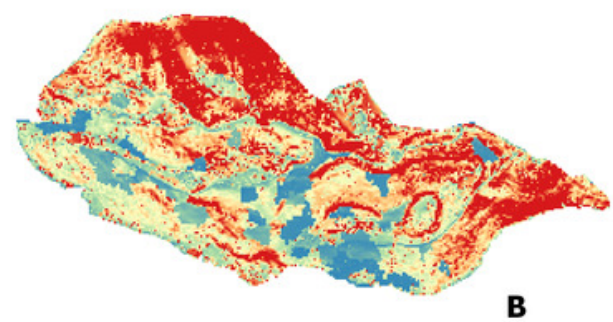

B

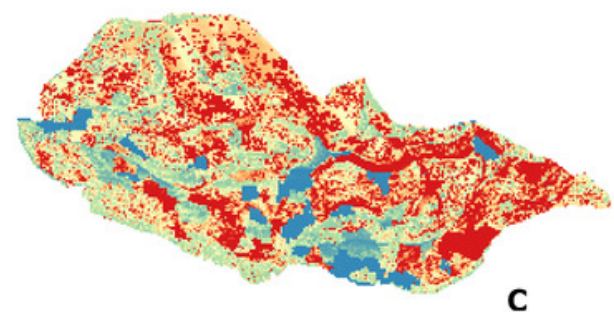

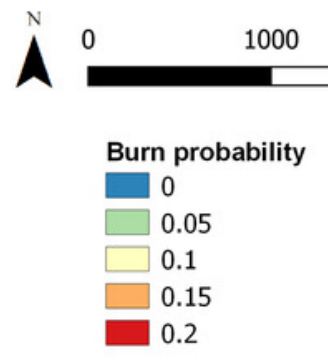

Spread rate $(\mathrm{m} / \mathrm{min})$

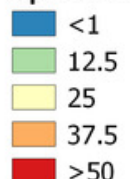

Flame length (m)

$\square<1$

$\square 12.5$

$\square 25$

37.5

$>50$

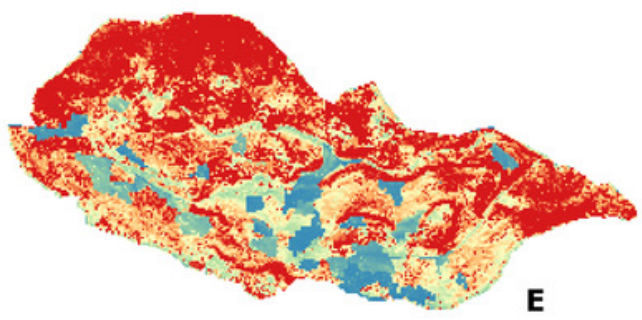

Levant wind
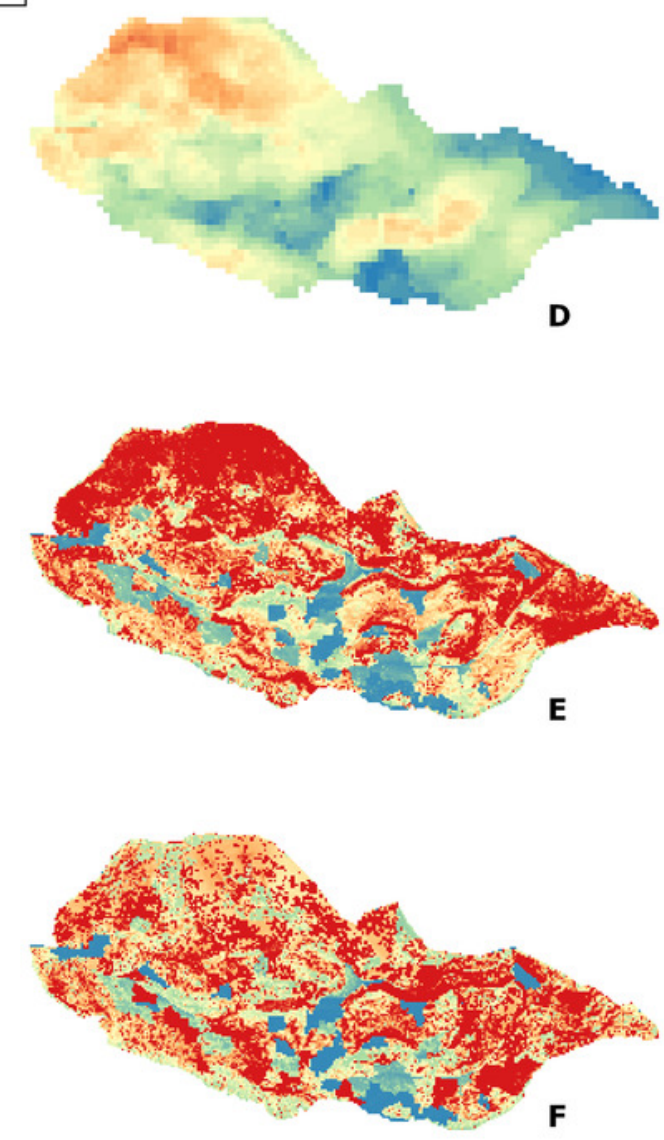


\section{Figure 6}

Frequency histograms for canopy height (Ho, graph A) and canopy cover (CC; graph B) values, as derived from regressions between Forestereo and LIDAR data, in the studied A. pinsapo forest
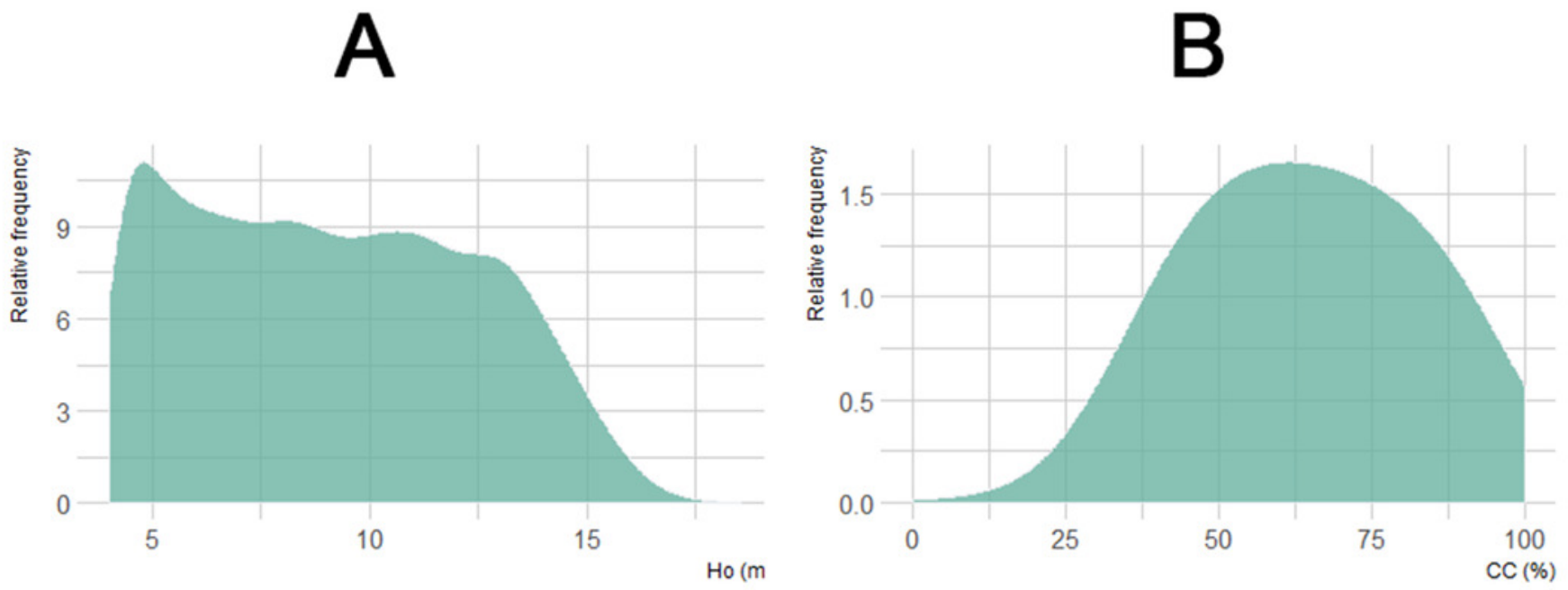


\section{Figure 7}

Photograph showing the widespread decline and dieback processes (stand stagnation, tree mortality, forest gap opening) that $A$. pinsapo forests are experiencing in the study area.

The die-back process of $A$. pinsapo forests stimulates the production of R4 fuel model (abundant dead wood and debris accumulation).

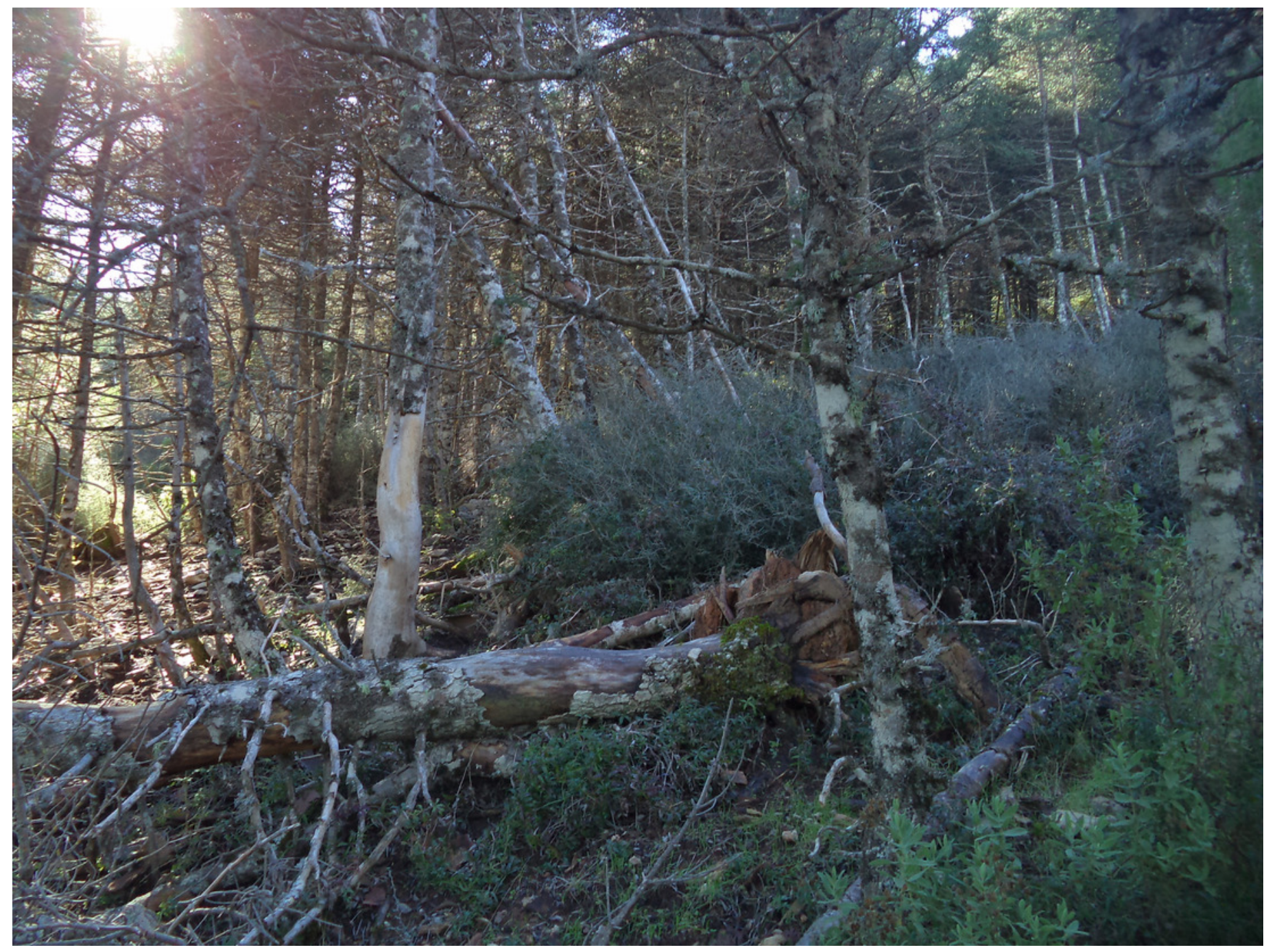




\section{Table $\mathbf{1}$ (on next page)}

Fuel model classification obtained following the UCO40 criteria (Rodríguez y Silva \& Molina-Martínez, 2012), based on Scott \& Burgan (2005).

Dead fuel models are classified by the time lag: the time required for the moisture content of a fuel to respond to within $2 / 3$ of the new equilibrium moisture content. Larger diameter fuels have longer time lags, so they respond slower to environmental changes (Anderson 1982). LiveH: Live herbaceous fuel, LiveW: Live wood fuel. Moisture of extinction (\%): moisture content that prevents flame from propagating. 


\begin{tabular}{lccccccc}
\hline \multicolumn{7}{c}{ Fuel loading (tn/ha) } \\
\cline { 2 - 5 } Fuel type & $\begin{array}{l}\text { Time lag } \\
\mathbf{1 h}\end{array}$ & $\mathbf{1 0 h}$ & $\mathbf{1 0 0 h}$ & LiveH & LiveW & $\begin{array}{c}\text { Moisture of } \\
\text { extinction (\%) }\end{array}$ & Fuel bed depth (cm) \\
\hline Predominance of shrubs & & & & & \\
M3 & 11.47 & 2.88 & 3.37 & 0 & 6.10 & 15 & 82.29 \\
M8 & 11.23 & 6.10 & 3.47 & 0 & 7.27 & 30 & 121.92 \\
M9 & 34.71 & 9.86 & 4.93 & 0 & 18.89 & 15 & 182.88 \\
Pine-needle litter with shrubs and/or grassland under forest canopy & \\
HPM4 & 17.63 & 13.23 & 1.17 & 0 & 11.13 & 20 & 76.2 \\
Predominance of pine-needle with branches and other canopy debris & \\
HR7 & 0.73 & 3.76 & 3.47 & 0 & 0 & 25 & 18.28 \\
Predominance of canopy debris accumulation & & & \\
R4 & 1.57 & 5.16 & 6.29 & 0 & 0 & 25 & 82 \\
\hline
\end{tabular}

2

3

4

5

6

7 


\section{Table 2 (on next page)}

Dead fuel moisture conditioning

Weather stream file (.WXS) showing typical summer weather circadian change in the area, used as input to Flammap software for quantifying the moisture of dead fuel. 
1

\begin{tabular}{|c|c|c|c|c|c|c|}
\hline$\overline{\text { Date }}$ & $\mathrm{T}\left({ }^{\circ} \mathrm{C}\right)$ & RH (\%) & PP (mm) & Wind SP (m/s) & Wind dir. $\left(^{\circ}\right)$ & Cloud (\%) \\
\hline $08 / 27 / 1410: 00$ & 28 & 33 & 0 & 2 & 180 & 0 \\
\hline 08/27/14 11:00 & 29 & 32 & 0 & 2 & 180 & 0 \\
\hline 08/27/14 12:00 & 30 & 29 & 0 & 1 & 180 & 0 \\
\hline 08/27/14 13:00 & 31 & 27 & 0 & 2 & 180 & 0 \\
\hline 08/27/14 14:00 & 30 & 27 & 0 & 2 & 180 & 0 \\
\hline 08/27/14 15:00 & 29 & 28 & 0 & 2 & 180 & 0 \\
\hline 08/27/14 16:00 & 29 & 29 & 0 & 2 & 180 & 0 \\
\hline 08/27/14 17:00 & 28 & 30 & 0 & 1 & 180 & 0 \\
\hline 08/27/14 18:00 & 27 & 31 & 0 & 2 & 180 & 0 \\
\hline 08/27/14 19:00 & 26 & 32 & 0 & 2 & 180 & 0 \\
\hline
\end{tabular}

2

3

4

5

6

7 


\section{Table 3 (on next page)}

Best regression models between LIDAR data (independent variable) and field-based Forestereo data (dependent variable), used to map spatial distribution of the main forest structure variables

To find which LIDAR data best suit to each field data, a correlation matrix was done. The best results $(R>0.5$ and $p$-value $<0.05)$ were tested by using linear, power and exponential regression models. The models with highest $R^{2}$ and lower RMSE were selected. CC: canopy cover; Ho: stand height; CBH: canopy base height; CBD: canopy bulk density; G: basal area. $x$ : Percentage of LIDAR first returns above $4 m, y$ : Percentage of all returns above $4 m, z$ : Percentage of all returns above mean, $d$ : Percentage of first returns above $0.25 \mathrm{~m}$. 
1

\begin{tabular}{llll}
\hline $\begin{array}{l}\text { Dependent } \\
\text { variable }\end{array}$ & Predictive model & $\mathbf{R}^{2}$ & RMSE (\%) \\
\hline $\mathrm{CC}$ & $\mathrm{x} \cdot 0.92023$ & 0.84 & 17.7 \\
Ho & $0.1469 \cdot \mathrm{y}$ & 0.61 & 55.7 \\
$\mathrm{CBH}$ & $\mathrm{x}^{0.013839}$ & 0.43 & 83.3 \\
$\mathrm{CBD}$ & $\mathrm{z} \cdot 0.007893$ & 0.64 & 59.5 \\
$\mathrm{G}$ & $\mathrm{d} \cdot 9.28 \cdot 10^{-8}$ & 0.61 & 67.3 \\
\hline
\end{tabular}




\section{Table 4(on next page)}

Confusion matrix of the Nearest Neighbor classification for the fuel models

User accuracy: how often the class on the map will actually be present on the ground. Producer accuracy: How often are real features on the ground correctly shown on the classified map. 


\section{Predicted classes}

\begin{tabular}{|c|c|c|c|c|c|c|c|}
\hline & M3 & M8 & M9 & HPM4 & HR7 & R4 & Sum \\
\hline \multicolumn{8}{|c|}{ Fuel type observed in field } \\
\hline M3 & 2 & 0 & 0 & 1 & 2 & 0 & 5 \\
\hline M8 & 0 & 5 & 1 & 0 & 0 & 0 & 6 \\
\hline M9 & 3 & 0 & 3 & 0 & 0 & 0 & 6 \\
\hline HPM4 & 0 & 0 & 0 & 2 & 2 & 1 & 5 \\
\hline HR7 & 0 & 1 & 0 & 0 & 0 & 1 & 2 \\
\hline $\mathbf{R 4}$ & 0 & 0 & 0 & 0 & 0 & 3 & 3 \\
\hline Sum & 5 & 6 & 4 & 3 & 4 & 5 & \\
\hline \multicolumn{8}{|l|}{ Accuracy } \\
\hline Producer & 0.4 & 0.83 & 0.75 & 0.7 & 0 & 0.6 & \\
\hline User & 0.4 & 0.83 & 0.5 & 0.4 & 0 & 1 & \\
\hline \multicolumn{4}{|c|}{ Overall accuracy } & \multicolumn{4}{|c|}{ KIA } \\
\hline \multicolumn{4}{|c|}{0.56} & \multicolumn{4}{|c|}{0.46} \\
\hline
\end{tabular}

2

3

4

5

6

7 